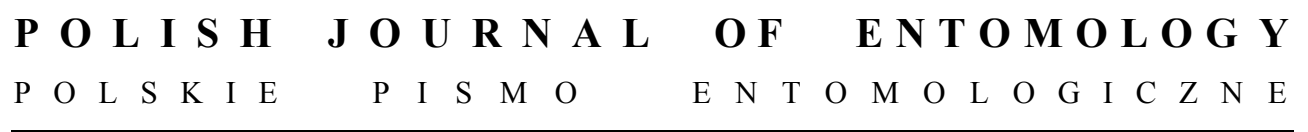

VOL. 82: 19-24

Gdańsk

31 March 2013

DOI: $10.2478 / \mathrm{v} 10200-012-0019-6$

\title{
Development of the rosalia longicorn Rosalia alpina (L.) (Coleoptera: \\ Cerambycidae) in the sycamore maple Acer pseudoplatanus L. - the first report from Poland
}

\author{
JAKUB MiCHALCEWICZ ${ }^{1}$, JAN BODZIARCZYK ${ }^{2}$, MiCHA£ CIACH ${ }^{3}$ \\ ${ }^{1}$ Department of Forest Protection, Entomology and Forest Climatology, Faculty of Forestry, \\ University of Agriculture, Al. 29 Listopada 46, 31-425 Kraków, Poland, \\ e-mail: j.michalcewicz@ur.krakow.pl; \\ ${ }^{2}$ Department of Botany and Nature Conservation, Forest Biodiversity Institute, \\ Faculty of Forestry, University of Agriculture, Al. 29 Listopada 46, 31-425 Kraków, \\ Poland, e-mail: rlbodzia@cyf-kr.edu.pl; \\ ${ }^{3}$ Department of Zoology and Wildlife Management, Forest Biodiversity Institute, \\ Faculty of Forestry, University of Agriculture, Al. 29 Listopada 46, 31-425 Kraków, \\ Poland, e-mail: michal.ciach@ur.krakow.pl
}

\begin{abstract}
In 2012 the development of the rosalia longicorn Rosalia alpina (L.) was confirmed in the sycamore maple Acer pseudoplatanus L., a new host plant in Poland. In the laboratory, one adult beetle was reared from a branch obtained from the Magura National Park (Beskid Niski Mts., Carpathians, SE Poland). The breeding material was collected at a site located in the fertile Carpathian beech forest association Dentario glandulosae-Fagetum, in a stand with an admixture of sycamore maple trees. In the paper the importance of the sycamore maple as a host plant is discussed.
\end{abstract}

KEY WORDS: Rosalia alpina, Acer pseudoplatanus, Carpathians, Beskid Niski Mts., Magura National Park, host plant.

\section{INTRODUCTION}

The rosalia longicorn Rosalia alpina (L.), a rare saproxylic species, occurs mainly in old mountain beech forests (BURAKOWSKI et al. 1990). Ecologically, this species is associated with Fagus L. (SAMA 2002), but other tree species have also been reported as its larval host 
plants (see references in MichALCEWICZ et al. 2011). In Poland, the rosalia longicorn has been recorded in the largest numbers in the Beskid Niski and the Bieszczady Mts. (both ranges belong to the Carpathians) (STARZYK 2004). The European beech Fagus sylvatica L. was the only known host plant of rosalia longicorn larvae in Poland (DOMINIK \& STARZYK 1989, STARZYK 2004) until larvae of this beetle were discovered feeding on wych elm Ulmus glabra HUdS. (CIACH et al. 2007, CIACH \& MiCHALCEWICZ 2009, MiCHALCEWICZ et al. 2011).

In 2012, field studies and laboratory rearing yielded yet another host plant (so far unknown in Poland) of rosalia longicorn larvae in the Magura National Park in the Beskid Niski Mts.

\section{Acknowledgements}

The authors wish to extend their gratitude to Andrzej Czaderna M.Eng., Director of the Magura National Park, for his assistance during the research, and to Dr. Radosław Wasik from the Department of Forest and Wood Utilization, University of Agriculture in Kraków, for his assistance in the identification of the host plant wood.

\section{FIELD METHODS AND LABORATORY REARING}

Potential sites of the occurrence of the rosalia longicorn were searched for during research into the species' ecology in the Polish Carpathians in 2012. Timber yards and localities where European beech trees naturally decay in forest stands were inspected. The records reported are the result of focused exploration in the Magura National Park.

The Magura National Park is situated in the Beskid Niski Mts. (SE Poland) and is covered mainly by a mosaic of woodlands, which make up $96 \%$ of the total area. Fertile Carpathian beech forest Dentario glandulosae-Fagetum is the dominant forest plant community within the national park, and the European beech and the silver fir Abies alba MiLL. are the dominant tree species.

On 19 May 2012 a dead sycamore maple Acer pseudoplatanus branch, found on Mt. Kamien near the village of Krempna in the Magura National Park (Fig. 1), was obtained for laboratory rearing. The exact position of the habitat is not given for conservation reasons. The branch $-2 \mathrm{~m}$ long and $15 \mathrm{~cm}$ in diameter at the thick end - was taken from the ground next to a live sycamore maple tree (trunk circumference $=154 \mathrm{~cm}$ at breast height), from which it had broken off at a height of at least ca $11 \mathrm{~m}$.

\section{The material examined}

A sycamore maple branch - Beskid Niski Mts., Magura National Park, Mt. Kamień near Krempna (UTM: EV38), 19 May 2012; 1 ex. of the rosalia longicorn $R$. alpina imago, ex cult. - recorded on 11 June 2012 (leg. et cult. J. Michalcewicz). 


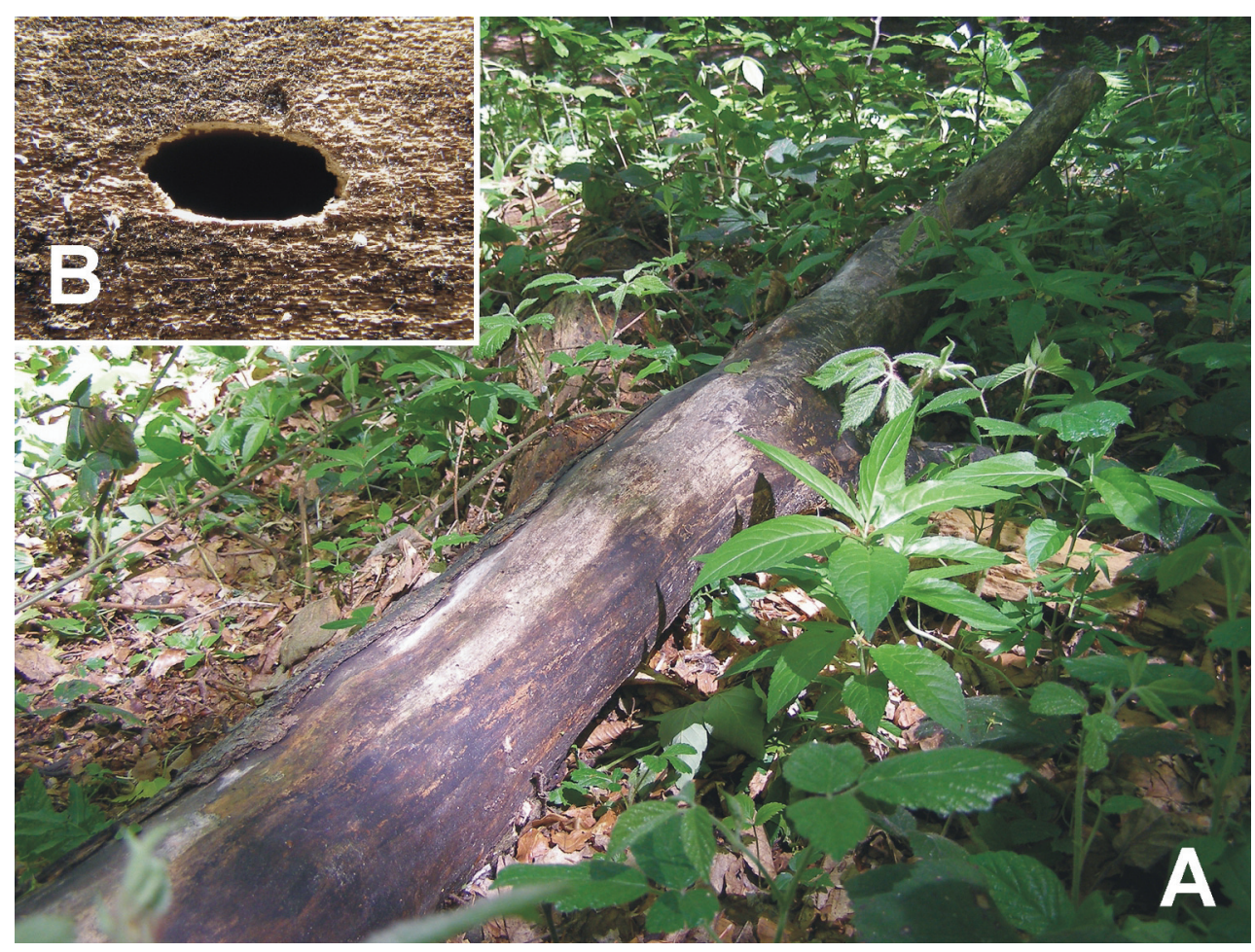

Fig. 1. A - a sycamore maple Acer pseudoplatanus L. branch as a breeding material of the rosalia longicorn Rosalia alpina (L.), Magura National Park (SE Poland), 19 May 2012; B - an imago exit hole obtained from this material during laboratory rearing (photo: J. Michalcewicz).

Description of the vegetation community, i.e. habitat of the rosalia longicorn Rosalia alpina on Mt. Kamień (Magura National Park, Beskid Niski Mts., SE Poland) was made on 27 June 2012 with the BRAUN-BLANQUET (1964) method (scientific names are according to MIREK et al. (2002)). Characteristics were: altitude: $640 \mathrm{~m}$, slope aspect: $\mathrm{N}$, inclination: $5-7^{\circ}$, relevé area: $400 \mathrm{~m}^{2}$, cover of trees $-\mathrm{A}_{1}: 95 \%, \mathrm{~A}_{2}: 10 \%$; cover of the shrub layer $(\mathrm{B})$ : 25\%; herb cover (C): 100\%; trees, $\mathrm{A}_{1}$ : Fagus sylvatica 4, Acer pseudoplatanus $3 ; \mathrm{A}_{2}$ : Fagus sylvatica 2; B: Fagus sylvatica 3; C: Acer pseudoplatanus (seedlings) +, Fagus sylvatica (seedlings) +, Sorbus aucuparia +; Shrubs: Corylus avellana 1; Herbs: Rubus hirtus 4, Dryopteris filix-mas 1, Dentaria glandulosa 1, Veronica montana 1, Senecio ovatus 1, Galium odoratum 3, Lysimachia nemorum 1, Symphytum cordatum 1, Oxalis acetosella 1, Athyrium filix-femina 1, Glechoma hirsuta 1, Impatiens noli-tangere +, Dryopteris affinis +, Circaea lutetiana 1, Galeobdolon luteum 1, Geranium robertianum +, 
Pulmonaria obscura + , Urtica dioica + , Aegopodium podagraria + , Stellaria nemorum + , Stachys sylvatica + , Carex sylvatica + , Dentaria bulbifera + , Dryopteris dilatata + , Anemone nemorosa + , Mercurialis perennis 2.

\section{RESULTS AND DISCUSSION}

As a result of laboratory rearing, one rosalia longicorn imago was obtained from the aforementioned branch. The breeding material with the larval gallery near the exit hole of the imago (9.8 mm in width and $4.5 \mathrm{~mm}$ in height) (Fig. 1) had a diameter of $11 \mathrm{~cm}$. The habitat of the species is fertile Carpathian beech forest, where the European beech and sycamore maple are the dominant species in the canopy (Fig. 2).

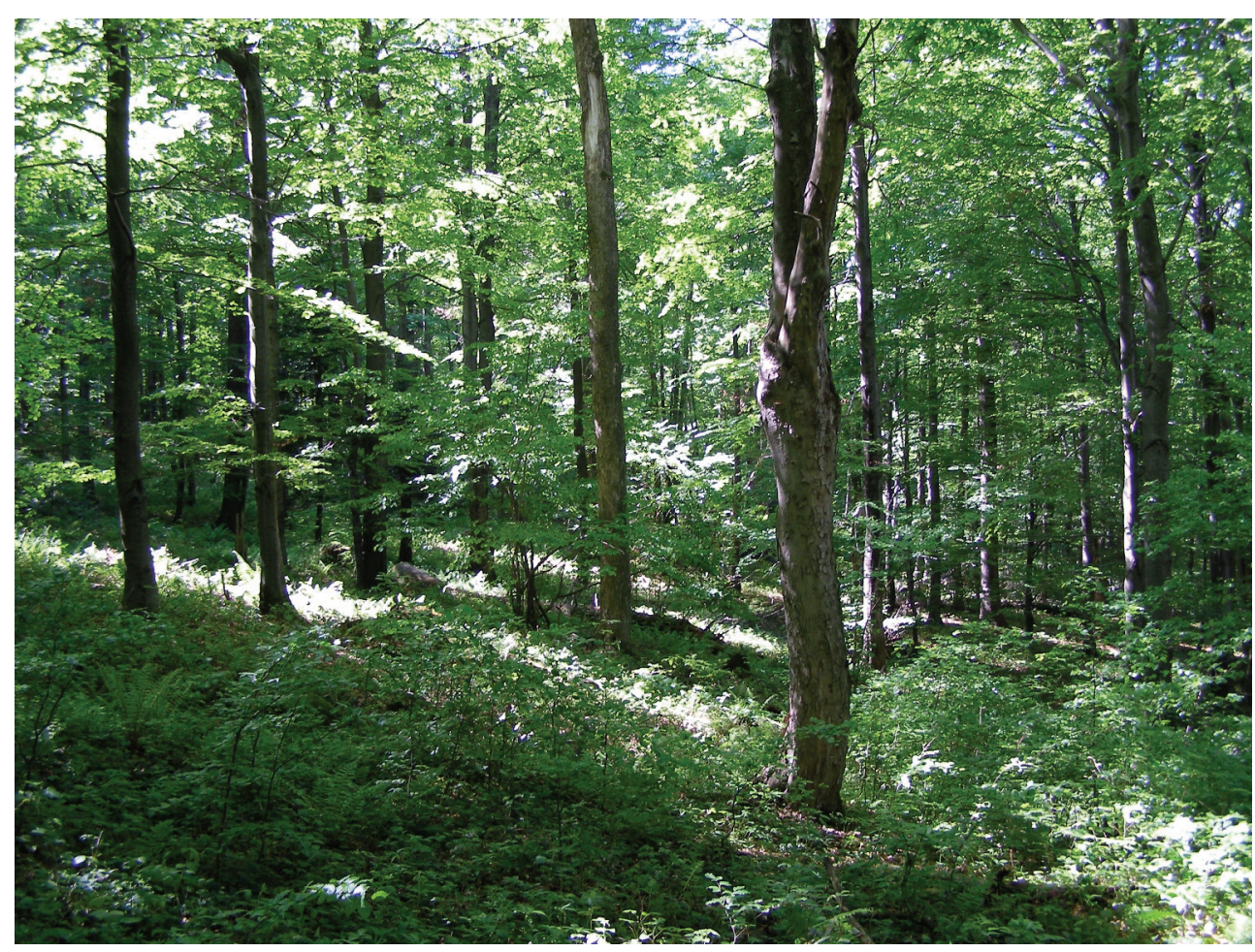

Fig. 2. The habitat of the rosalia longicorn Rosalia alpina (L.) in the Magura National Park (SE Poland) where larval development in sycamore maple Acer pseudoplatanus L. wood was observed, 19 May 2012 (photo: J. Michalcewicz). 
Well-documented reports from Central Europe on the development of the rosalia longicorn larvae in trees other than the European beech include the following genera and species: wych elm, most likely European white elm Ulmus laevis PALL., lime Tilia spp., sycamore maple, field maple $A$. campestre L., Norway maple A. platanoides L., ash Fraxinus sp. and probably European hornbeam Carpinus betulus L. (i.a. MerkL et al. 1996, CiaCH et al. 2007, Ciach \& MichalCEWicz 2009, ČížEK et al. 2009, Michalcewicz et al. 2011, U. BENSE pers. comm.). The sycamore maple is a host plant for rosalia longicorn larvae in Hungary, Austria and Germany (KovÁCS 1998, KovÁCs et al. 2000, ZÁBRANSKÝ 2001, BINNER \& BUSSLER 2006, and U. BENSE pers. comm.). The record described in this paper is the first report from Poland of the sycamore maple being used by rosalia longicorn larvae as a host plant. This could indicate a shift in the species' food preferences or be the result of inadequate previous knowledge of ecology of the species.

Information on the habitat selection of the rosalia longicorn indicates its preference for insolated breeding material (see GUTOWSKI 2004, STARZYK 2004, RUSSO et al. 2011). However, the breeding material described in this paper was sheltered by the tree canopy and the site's northern aspect, where the insolation will have been less than favourable. The results of the present study indicate that development of the rosalia longicorn is also possible in forest stands with a dense canopy of trees. It is likely, however, that the branch was populated before it was broken off, having been located in the crown, where favourable thermal and moisture conditions will have prevailed.

Observations of the rosalia longicorn in the Beskid Niski Mts. in previously unknown habitats (roadside trees, a forest clearing community in the successional stage), reports of the wych elm as a new host plant (Ciach et al. 2007, Ciach \& MichalcewicZ 2009, MichalCEWICZ et al. 2011, MichalCEWICZ \& CiACH 2012), as well as the development of the rosalia longicorn in sycamore maple wood, described in this paper, may be consequences of ongoing changes in the species' ecology.

The evidence for the rosalia longicorn's development in sycamore maple wood requires a different approach to the current threats and protection of this longhorn beetle in Poland. Henceforth, the sycamore maple must be included among the species that should be treated with caution when it comes to the logging, or the removal of dying and dead trees and their remains.

\section{REFERENCES}

BinNER V., Bussler H. 2006. Erfassung und Bewertung von Alpenbock-Vorkommen. Naturschutz und Landschaftsplanung 38: 378-382.

Braun-Blanquet J. 1964. Pflanzensoziologie. Grundzüge der Vegetationskunde. 3. Auflage Springer Verlag, Wien, XIV + 865 pp.

Burakowski B., Mroczkowski M., Stefańska J. 1990. Beetles - Coleoptera. Cerambycidae and Bruchidae. Catalogue of Polish Fauna XXIII, 15. PWN, Warszawa. [In Polish]. 
Ciach M., Michalcewicz J. 2009. Egg morphology of Rosalia alpina (Linnaeus, 1758) (Coleoptera: Cerambycidae) from southern Poland. Entomological News 120: 61-64. DOI: 10.3157/021.120.0112.

Ciach M., Michalcewicz J., Fluda M. 2007. The first report on development of Rosalia alpina (Linnaeus, 1758) (Coleoptera: Cerambycidae) in wood of Ulmus L. in Poland. Polish Journal of Entomology 76: 101-105.

Č́̇̌žek L., Schlaghamerský J., BoŘUckÝ J., Hauck D., Helešic J. 2009. Range expansion of an endangered beetle: Alpine Longhorn Rosalia alpina (Coleoptera: Cerambycidae) spreads to the lowlands of Central Europe. Entomologica Fennica 20: 200-206.

DOMINIK J., STARZYK J.R. 1989. Ochrona drewna. Owady niszczące drewno. PWRiL, Warszawa, 524 pp.

Gutowski J.M. 2004. Rosalia alpina (LinNaeus, 1758), Nadobnica alpejska. [In:] AdAmSKi P., BARTEl R., BereszyŃSKi A., KePel A., WitKowsKi Z. (eds). Gatunki zwierząt (z wyjątkiem ptaków). Poradniki ochrony siedlisk i gatunków Natura 2000 - podręcznik metodyczny. Tom 6. Ministerstwo Środowiska, Warszawa, pp.: 130-134.

KovÁCS T. 1998. Magyarországi cincérek tápnövény- és lelöhelyadatai II. (Coleoptera, Cerambycidae). [Foodplants and locality data of Hungarian longhorn beetles II. (Coleoptera: Cerambycidae)]. Folia Historico Naturalia Musei Matraensis 22 (1997): 247-255.

KovÁCs T., Muskovits J., HegYessy G. 2000. Magyarországi cincérek tápnövény- és lelöhelyadatai III. (Coleoptera: Cerambycidae). [Foodplants and locality data of Hungarian longhorn beetles III. (Coleoptera: Cerambycidae)]. Folia Historico Naturalia Musei Matraensis 24: 205-220.

Merkl O., Hegyessy G., KovÁcs T. 1996. Cerambycidae (Coleoptera) from the Bükk National Park. [In:] MahunkA S. (ed.). The Fauna of the Bükk National Park, II. Hungarian Natural History Museum, Budapest, pp.: 309-326.

Michalcewicz J., Ciach M. 2012. Rosalia longicorn Rosalia alpina (L.) (Coleoptera: Cerambycidae) uses roadside European ash trees Fraxinus excelsior L. - an unexpected habitat of an endangered species. Polish Journal of Entomology 81: 49-56. DOI: 10.2478/v10200-011-0063-7.

Michalcewicz J., Ciach M., BodziarCZYK J. 2011. The unknown natural habitat of Rosalia alpina (L.) (Coleoptera: Cerambycidae) and its trophic association with the mountain elm Ulmus glabra in Poland - a change of habitat and host plant. Polish Journal of Entomology 80: 23-31. DOI: 10.2478/v10200-011-0003-6.

Mirek Z., PięKoś-Mirkowa H., ZająC A., ZajĄC M. 2002. Flowering plants and pteridophytes of Poland. A checklist. W. Szafer Institute of Botany, Polish Academy of Sciences, 442 pp.

Russo D., Cistrone L., GARONNA A. 2011. Habitat selection by the highly endangered long-horned beetle Rosalia alpina in Southern Europe: a multiple spatial scale assessment. Journal of Insect Conservation 15: 685-693.

SAMA G. 2002. Atlas of the Cerambycidae of Europe and the Mediterranean Area. Volume 1. Northern, Western, Central and Eastern Europe. British Isles and Continental Europe from France (excl. Corsica) to Scandinavia and Urals. Nakladatelství Kabourek, Zlín, 173 pp.

StARZYK J.R. 2004. Rosalia alpina (LinNAeus, 1758), Nadobnica alpejska. [In:] GŁOWACIŃSKi Z., NOWACKI J. (eds). Polska czerwona księga zwierząt. Bezkręgowce. IOP PAN Kraków, AR Poznań, pp.: 148-149.

ZÁBRANSKÝ P. 2001. Xylobionte Käfer im Wildnisgebiet Dürrenstein. [In:] LIFE-Projekt Wildnisgebiet Dürrenstein. Forschungsbericht. Amt der Niederösterreichischen Landesregierung, St. Pölten, pp.: 149-179.

Received: December 15, 2012

Accepted: February 25, 2013 